\title{
KAJIAN TEKNIS \& KeEKONOMIAN PEMBANGKIT LISTRIK TENAGA BIOMASA SAWIT; KaSUS: Di PABRIK Kelapa SAWIT PinAng Tinggi, Sei BAHAR, JAMBI
}

\author{
Irhan Febijanto \\ Pusat Teknologi Pengembangan Sumberdaya Energi, \\ Deputi Teknologi Informatika, Energi dan Mineral- BPPT \\ Gedung II, Lt. 22,Jl. M.H. Thamrin No. 8, Jakarta Pusat \\ Jakarta 10340, Indonesia \\ irhan.febijanto@gmail.com
}

Diterima: 30 Maret 2011; Direvisi: 11 April 2011; Disetujui: 23 April 2011;

Terbit online: 7 Juli 2011.

\begin{abstract}
Abstrak
Pemanfaatan limbah tandan kosong sebagai bahan bakar pembangkit listrik merupakan salah satu pilihan Pabrik Kelapa Sawit (PKS) dalam usaha penanggulangan limbah tandan kosong. Limbah tandan kosong saat ini belum banyak dimanfaatkan karena beberapa pilihan untuk pemanfaatan seperti penggunaan untuk bahan baku pupuk dan kompos sudah dilaksanakan akan tetapi hasilnya tidak efektif, terutama dalam pengolahan tandan kosong dalam jumlah besar. Jumlah Pembangkit Listrik Berbahan Bakar Limbah Biomasa Sawit yang menggunakan bahan bakar tandan kosong tidak banyak di Indonesia. Makalah ini menjelaskan secara teknis dan keekonomian pemanfaatan limbah tandan kosong di PKS Pinang Tinggi, Sei Bahar, Propinsi Jambi, untuk pembangkit listrik. Listrik di jual ke PT PLN (Persero). Kelayakan keekonomian sangat rendah jika pendapatan tambahan dari penjualan remnant oil, abu sisa pembakaran dan penjualan kredit karbon tidak dimasukkan sebagai pendapatan. Ketiga pendapatan tambahan dapat meningkatkan IRR proyek dari 2,03\% menjadi 15,12\%. Besarnya nilai investasi dan harga jual listrik sangat menentukan sensivitas keekonomian proyek.
\end{abstract}

Kata Kunci: pabrik kelapa sawit, tandan kosong, cangkang, gas rumah kaca, kredit karbon.

\begin{abstract}
Utilization of empty fruit bunch (EFB) waste as a fuel for power electric generation is one of the options available for palm oil factory in the effort to reduce EFB waste. At the moment, there are several options to utilize EFB waste such as fertilization and composting. However, both ways show ineffective result, particularly in handling huge amount of EFB. Up to now, Indonesia only has a limited number of EFB fueled power plants. This paper explains technically and economically EFB fueled power plant supplying to PLN grid in Pinang Tinggi Palm Oil Factory located at Sei Bahar, Jambi Province. The economical feasibility is low, if the additional revenue generated from selling remnant oil, selling ash of EFB and selling credit carbon are not counted as an income. Using these additional revenues, the IRR project increased from $2.03 \%$ to $15.12 \%$. The investment cost and the selling electricity price are critical sensitivity factors for project economics.
\end{abstract}

Keyword: palm oil factory, empty fruit bunch, shell, green houses gasses, carbon credit.

\section{Pendahuluan}

\section{A. Latar Belakang}

Limbah padat di Pabrik Kelapa Sawit (PKS) terdiri dari tandan kosong (empty fruit bunch/EFB atau TKS), cangkang (shell) dan serabut (fibre). Pemanfaatan limbah padat, cangkang dan serabut sebagai bahan bakar sudah dilakukan pada ketel uap (boiler) di PKS untuk menghasilkan uap air/steam untuk kebutuhan proses pabrik, dan membangkitkan listrik untuk kebutuhan pabrik maupun perumahan pegawai di sekitar PKS.

Karakteristik tandan kosong berbeda dengan cangkang dan serabut, hal ini menyebabkan tandan kosong tidak dapat digunakan sebagai sumber energi secara langsung dengan menggunakan fasilitas yang sama dengan cangkang dan serabut. Tandan kosong diketahui mengandung moisture/kandungan air yang sangat tinggi sekitar 50\%-60\%, dan mengandung potasium (K) yang mencapai 2,4\% [1], selain itu juga diketahui mengandung klorin (Cl). Efek korosi akan meningkat dengan meningkatnya kandungan $\mathrm{Cl}$, dan unsur potasium dapat berperan dalam pembentukan deposit pada superheater yang dapat mengganggu proses pemindahan panas di tungku bakar [2].

Karakteristik yang berbeda dari TKS (Tandan Kosong), menyebabkan dibutuhkannya teknologi yang khusus dalam pemanfaatannya sebagai 


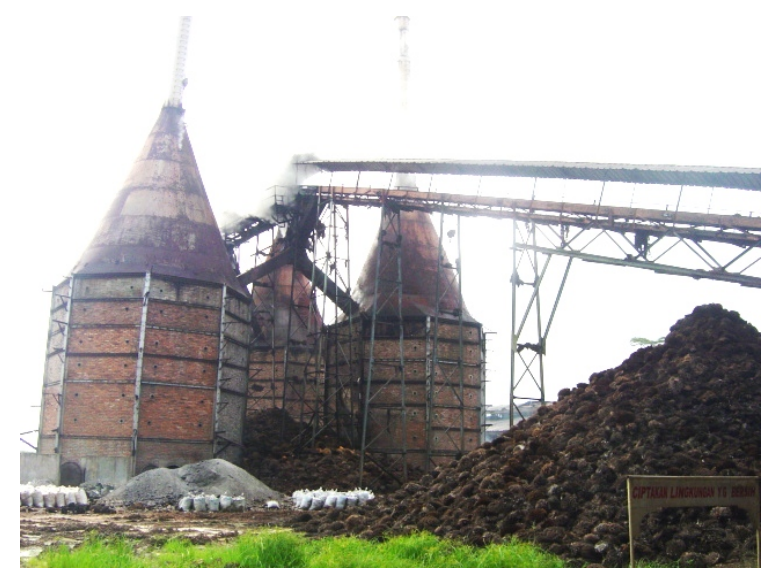

Gambar 1. Fasilitas pembakaran tandan kosong.

bahan bakar. Pada prinsipnya untuk meningkatkan efisiensi pembakaran, kandungan air TKS harus dikurangi sampai sekitar $40 \%$ dan efek dari unsur unsur alkali harus diatasi. Penyemprotan zat aditif kimia dengan menggunakan sootblower ke permukaan pipa di dalam tungku bakar merupakan salah satu teknik untuk mengurangi pengaruh unsur unsur alkali seperti terjadinya deposit, sintering dan efek lainnya [3].

Tetapi pada umumnya karena keterbatasan dana dan teknologi maka tandan kosong hanya dikumpulkan di sekitar PKS untuk dibakar begitu saja. Abu hasil pembakaran dipakai untuk pupuk oleh para petani di sekitar PKS. Fasilitas pembakaran yang umumnya digunakan di beberapa PKS ditunjukan di Gambar 1.

Pada tahun 1996, dimulai program Langit Biru oleh Kementrian Lingkungan Hidup [4], sebagai dampaknya cara mengatasi limbah tandan kosong dengan cara pembakaran dilarang, karena menyebabkan pencemaran udara. Sebagai gantinya limbah tandan kosong digunakan sebagai pupuk dan atau bahan baku kompos. Akan tetapi pelaksanaannya tidak begitu membuahkan hasil yang baik, bahkan di beberapa tempat diketemukan ketidakefisienan dalam pelaksanaan. Pengembalian limbah tandan kosong sebagai bahan baku pupuk alam dan pengganti pupuk buatan ke lahan perkebunan, membutuhkan biaya buruh dan solar untuk pengangkutan, sehingga menjadi beban tambahan. Biaya pelaksanaannya tidak dapat mengurangi biaya pembelian pupuk kimia. Dari hasil survei yang pernah dilakukan pengawasan pengembalian tandan kosong ke lahan pertanian tidak bisa dilaksanakan secara efektif, umumnya dibuang begitu saja di pinggir jalan, seperti ditunjukkan pada Gambar 2 [5].

Pelaksanaan pengkomposan juga membutuhkan biaya yang tidak sedikit, sehingga pemanfaatan limbah tandan kosong untuk pupuk dan kompos tidak banyak berlanjut karena

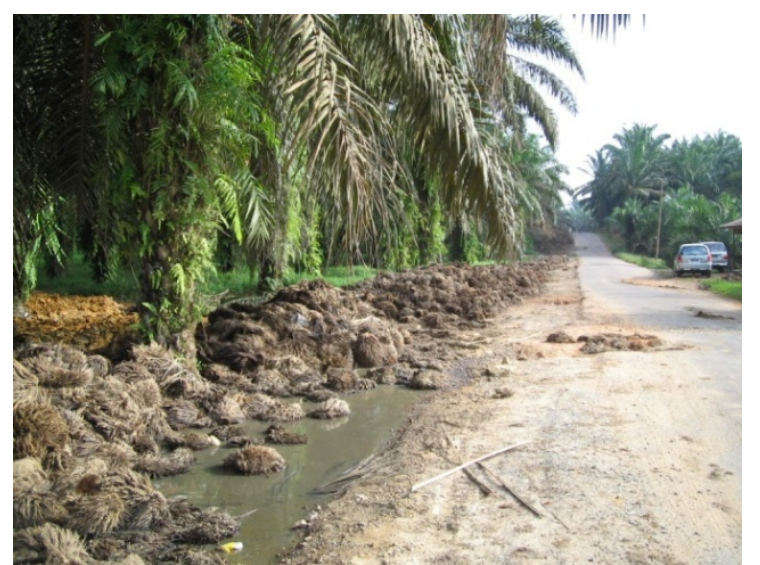

Gambar 2. Pelaksanaan pengembalian limbah tandan kosong ke lahan perkebunan yang tidak efektif.

tingginya biaya operasional dan kendala-kendala teknis lainnya.

Pemanfaatan tandan kosong sebagai bahan bakar boiler menjadi salah satu alternatif pilihan yang banyak dipertimbangkan akhir-akhir ini. Proyek pemanfaatan tandan kosong ini biasanya dikaitkan dengan perdagangan karbon melalui mekanisme CDM (Clean Development Mechanism). Ini menunjukkan bahwa proyek PLTBS (Pembangkit Listrik Tenaga Biomasa Sawit) yang menggunakan tandan kosong sebagai bahan bakar merupakan proyek yang tidak layak secara keekonomian jika hanya mendapatkan pendapatan dari hasil jual beli listrik. Proyek menjadi ekonomis jika ada pendapatan tambahan dari hasil jual beli emisi karbon yang dikurangi dengan beroperasinya PLTBS. Hal ini bisa menjadi salah satu alasan mengapa proyek PLTBS tidak ada sebelum Protokol Kyoto diratifikasi oleh pemerintah Indonesia pada tahun 2004.

Potensi energi dari tandan kosong ini sangat besar, cukup untuk memberikan kontribusi kekurangan listrik di pulau Sumatera. Dari 69 PKS di Sumatera yang dikelola PT Perkebunan Nusantara (PTPN), yang merupakan BUMN (Badan Usaha Milik Negara), tercatat potensi 10.000 ton/tahun tandan kosong dan jika dikonversikan ke daya listrik dengan asumsi efisiensi panas 21\%, maka limbah tandan kosong tersebut setara dengan pembangkit dengan kapasitas $510 \mathrm{MW}$ [6].

Potensi yang besar ini berusaha dimanfaatkan oleh PT PLN (Persero) dengan melakukan ikatan kerjasama dengan seluruh PTPN yang memiliki perkebunan kelapa sawit di Sumatera dan Kalimantan. Kerjasama ini telah ditandatangani pada bulan Januari 2010 [7]. Sebagai tindak lanjutnya, setiap PTPN melakukan studi potensi limbah tandan kosong untuk bahan bakar Pembangkit Listrik Tenaga Biomass Sawit. 


\section{B. Tujuan}

Tujuan dari studi ini adalah memberikan gambaran/estimasi perihal tingkat kelayakan teknis, nilai ekonomi dan finansial untuk pembangunan pembangkit listrik tandan kosong, atau disebut Pembangkit Listrik Tenaga Biomasa Sawit (PLTBS) di PKS Pinang Tinggi, PTPN VI, Jambi.

\section{Waktu dan Lokasi Penelitian}

Waktu penelitian dilakukan antara bulan Agustus 2010 hingga bulan Oktober 2010.Kandidat lokasi PLTBS adalah seluruh PKS milik PTPN VI, yang ditunjukkan di Tabel 1. Terdapat 5 PKS, 3 terletak di daerah Sungai Bahar (Sei Bahar) dan 2 PKS berlokasi di daerah Muara Bungo. Dimana hanya ada 2 PKS yang berkapasitas olah TBS (Tandan Buah Segar) sebesar 60 ton/jam.

\section{Metodologi}

Metodologi penentuan lokasi PLTBS mirip dengan penentuan aspek-aspek yang digunakan untuk penentuan lokasi PLTU, yaitu sebagai berikut:

1. Aspek fisik lokasi

Aspek fisik lokasi berkaitan dengan kondisi dan karakteristik fisik lokasi yang ditunjukkan oleh kondisi umum, kondisi geologi, kondisi lingkungan dan sarana penunjang yang terletak pada lokasi yang bersangkutan. Penilaian aspek ini berdasarkan beberapa faktor di antaranya data seismik (gempa), data hasil survei penyelidikan tanah untuk penentuan kedalaman pondasi tiang bor, serta peta topografi lahan.

2. Aspek kelistrikan

Aspek kelistrikan berkaitan dengan kondisi dan karakteristik yang berpengaruh terhadap masalah kelistrikan yang ditunjukkan oleh parameter jarak terdekat terhadap jaringan transmisi.

Tabel 1.

Kapasitas pabrik kelapa sawit.

\begin{tabular}{lc}
\hline Pabrik Kelapa Sawit & $\begin{array}{c}\text { Kapasitas } \\
\text { ton TBS/jam }\end{array}$ \\
\hline Sungai Bahar & \\
Bunut & 60 \\
Pinang Tinggi & 60 \\
Tanjung Lebar & 30 \\
\hline Muara Bungo & \\
Rimbo Dua & 30 \\
Ophir & 50 \\
\hline
\end{tabular}

\section{Aspek jalan masuk}

Aspek jalan masuk berkaitan dengan kemudahan aksesibilitas lokasi yang akan mempengaruhi biaya transportasi.

4. Aspek bahan bakar dan air

Aspek bahan bakar dan air berkaitan dengan ketersediaan bahan bakar dan air di lokasi tersebut. Bahan bakar dalam hal ini adalah limbah biomasa sawit. Ketersediaan air selain digunakan untuk umpan pada boiler juga diperlukan sebagai air pendingin pada kondensor.

5. Aspek lingkungan

Aspek lingkungan berkaitan dengan kondisi lingkungan pada saat ini serta dampak yang mungkin timbul dengan didirikannya pembangkit listrik.

6. Aspek biaya

Aspek biaya berkaitan dengan biaya investasi dan biaya operasi pembangkit pada tiap-tiap lokasi yang dipilih, oleh karena itu menjadi faktor yang sangat dominan dalam pemilihan lokasi pembangkit.

Semua aspek tersebut di atas harus dipertimbangkan sehingga didapatkan lokasi pembangkit yang paling layak dan menguntungkan. Namun karena lokasi PLTBS berada di dalam area PKS maka aspek fisik, aspek jalan masuk dan aspek lingkungan tidak menjadi pertimbangan yang penting. Aspek kelistrikan, aspek sumber bahan bakar dan air, dan aspek biaya merupakan tiga faktor yang menjadi inti dari pokok pembahasan dalam laporan studi ini.

Setelah penentuan lokasi, maka dilakukan analisa data sesuai dengan konsep dasar pembangunanan PLTBS, meliputi penentuan konfigurasi fasilitas peralatan PLTBS disesuaikan dengan keberlanjutan suplai dari bahan bakar biomasa, TKS dan cangkang. Dari penetapan kapasitas fasilitas PLTBS dilakukan estimasi investasi harga fasilitas peralatan kemudian dilakukan analisa keekonomian.

Pendapatan dari PLTBS berasal dari hasil penjualan listrik ke PT PLN (Persero), ditambah dengan pendapatan tambahan dari penjualan kredit karbon, penjualan remnant oil dan penjualan abu sisa pembakaran.

\section{A. Penentuan Lokasi}

Seperti ditunjukkan dalam Tabel 1, PTPN VI memiliki 5 PKS, diantaranya adalah PKS Bunut dan Pinang Tinggi, yang berkapasitas 60 ton TBS/jam. Dengan dasar pertimbangan jumlah suplai Tandan Buah Segar (TBS) yang maksimal, maka pemilihan lokasi mengarah ke lokasi PKS 
berkapasitas 60 ton TBS/jam, yaitu PKS Bunut dan PKS Pinang Tinggi.

Dari perencanaan jangka pendek-menengah PTPN VI, diketahui bahwa TKS yang dihasilkan di PKS Bunut akan digunakan untuk bahan baku pembuatan kompos. Hal ini berarti limbah TKS di PKS ini sudah akan termanfaatkan, sehingga jumlah TKS yang dapat dimanfaatkan sebagai bahan bakar akan berkurang. Sebaliknya di PKS Pinang Tinggi, belum ada rencana pemanfaatan TKS. Karena itu PKS Pinang Tinggi dipilih sebagai kandidat lokasi PLTBS berdasarkan keberlanjutan jumlah suplai bahan bakar TKS.

Dari segi aspek kelistrikan, sampai tahun 2010, rasio elektrifikasi Provinsi Jambi baru mencapai $51,41 \%$ dan rasio desa berlistrik sebesar 99,43\%. Daftar tunggu PLN telah mencapai 31.371 permintaan atau sebesar 92,3 MVA, dimana permintaan serta defisit tersebut belum dapat dipenuhi oleh PLN dalam waktu dekat [8]. Produksi listrik PLTBS Pinang Tinggi ini direncanakan dapat memberikan kontribusi terhadap pemenuhan konsumsi pertumbuhan listrik di propinsi Jambi, sekaligus memperbaiki kualitas suplai listrik di sekitar daerah Sei Bahar, Jambi.

Lokasi PKS Pinang Tinggi, berada di area sekitar $01^{\circ} 57^{\prime} 45^{\prime \prime}$ Lintang Selatan dan $103^{\circ} 24^{\prime} 07^{\prime \prime}$ Bujur Timur.

\section{B. Jenis dan Lokasi Sumber Bahan Bakar}

Bahan bakar untuk PLTBS direncanakan berasal dari TKS dan kekurangannya berasal dari cangkang. Kekurangan bahan bakar tersebut akan disuplai dari PKS Bunut dan PKS Tanjung Lebar. Suplai bahan bakar dari kedua PKS dibatasi hanya suplai cangkang saja. Suplai TKS tidak memungkinkan karena kandungan air TKS mencapai sekitar 50\%, sehingga dari segi biaya transportasi tidak menguntungkan.

Dari Gambar 3, diketahui hanya posisi kedua PKS tersebut yang relatif dekat, berada dalam radius $10 \mathrm{~km}$ dari PKS Pinang Tinggi. Sedangkan

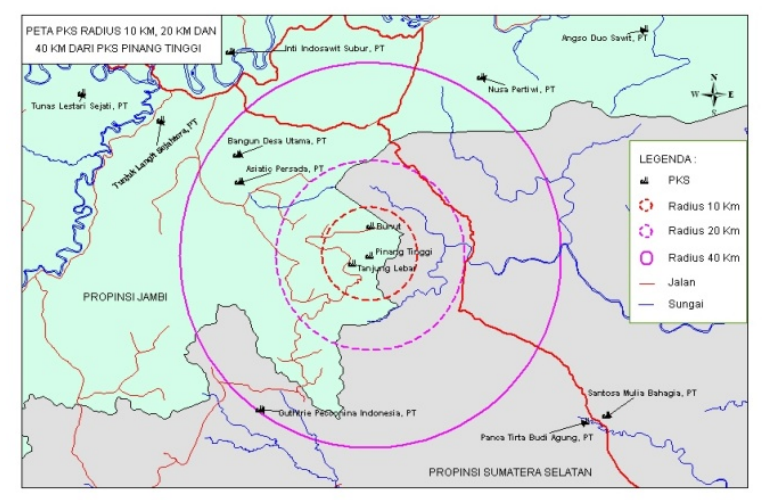

Gambar 3. Lokasi PKS di sekitar PKS Pinang Tinggi.

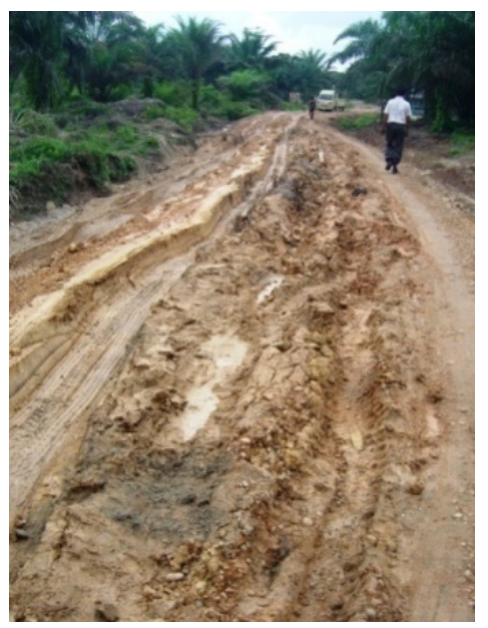

Gambar 4. Kondisi jalan pada saat musim hujan.

PKS lain berada di radius lebih dari $20 \mathrm{~km}$ yang membuat biaya transportasi sangat tidak menguntungkan.

Dari hasil survei lapangan diketahui bahwa jarak tempuh dari PKS Pinang Tinggi ke PKS Bunut berkisar $9 \mathrm{~km}$ dengan waktu tempuh ratarata 2 jam. Untuk mengangkut cangkang, jarak ini dapat ditempuh oleh truk pengangkut (kapasitas 5 ton) dengan 6 kali pulang-pergi (rit) dalam satu hari kerja. Sedangkan jarak tempuh dari PKS Pinang Tinggi ke PKS Tanjung Lebar berkisar $37 \mathrm{~km}$ dengan waktu tempuh 6 jam atau 2 kali pulang-pergi (rit) dalam satu hari kerja. Waktu tempuh akan menjadi lebih lama karena buruknya kondisi jalan terutama pada saat musim hujan, di beberapa lokasi, kondisi jalan berubah menjadi berlumpur dan berkubang seperti ditunjukkan Gambar 4.

\section{Potensi Jumlah Bahan Bakar}

Tujuan pembangunan PLTBS adalah untuk memanfaatkan jumlah limbah TKS sebagai sumber energi, dan mengurangi biaya pengolahan TKS semaksimal mungkin. Oleh karena itu direncanakan seluruh TKS dapat dimanfaatkan sebagai bahan bakar. Akan tetapi karena kendala jumlah TKS yang diproduksi PKS Pinang Tinggi tidak mencukupi maka dilakukan pencampuran cangkang seminimal mungkin.

Transportasi TKS dari PKS lain dihindari, karena kandungan airnya yang tinggi. Suplai tambahan bahan bakar dari PKS lain dibatasi hanya cangkang saja. Potensi jumlah cangkang dan jumlah TKS di PKS Pinang Tinggi ditunjukkan Tabel 2. Sedangkan potensi jumlah cangkang di PKS Tanjung Lebar dan PKS Bunut ditunjukkan pada Tabel 3.

Dalam perhitungan diasumsikan hanya 90\% dari potensi bahan bakar yang ditunjukkan Tabel 2 dan 3, yang dapat dimanfaatkan sebagai bahan bakar. 
Tabel 2 menunjukkan produksi TKS dan sisa cangkang di PKS Pinang Tinggi selama kurun 5 tahun yang lalu. Jumlah produksi TKS dan cangkang diasumsikan dari rasio TBS sebesar $23 \%$ dan cangkang 3,75\% [8].

Tabel 3 menunjukkan sisa cangkang di PKS Bunut dan PKS Tanjung Lebar selama 5 tahun berturut-turut dengan asumsi jumlah sisa cangkang adalah 3,75\% dari jumlah TBS olah [9]. Definisi sisa cangkang dalam studi ini adalah jumlah cangkang yang tersisa dari jumlah cangkang yang dimanfaatkan untuk bahan bakar boiler untuk memproduksi steam dan listrik (existing boiler) di PKS.

Dari Tabel 2 ditunjukkan total rata-rata jumlah TKS dalam 5 tahun (2005-2009) terakhir yang dapat dimanfaatkan adalah 49.174 ton/tahun, dan dari Tabel 2 dan 3, total jumlah sisa cangkang yang dapat dimanfaatkan adalah 21.646 ton/thn $(=8.018+7.875+5.843$ ton/thn $)$.

Penurunan massa TKS akibat penurunan kadar air diasumsikan bahwa pada kadar air 60\% massa TKS yang dapat dimanfaatkan adalah 49.174 ton/tahun. Sebagai perbandingan, Igwe memakai asumsi kadar air pada TKS 55-65\% [10]. Nasrin menggunakan nilai asumsi sebesar $67 \%$ [11].

Tabel 2.

Produksi TKS dan cangkang di PKS Pinang Tinggi.

\begin{tabular}{ccrr}
\hline \multirow{2}{*}{ Tahun } & \multicolumn{3}{c}{ Pinang Tinggi (ton) } \\
\cline { 2 - 4 } & TBS & $\begin{array}{c}\text { TKS } \\
(\mathbf{2 3 , 0} \%)\end{array}$ & $\begin{array}{r}\text { Cangkang } \\
\mathbf{( 3 , 7 5} \mathbf{\% )}\end{array}$ \\
\hline 2005 & 235,000 & 54,050 & 8,813 \\
\hline 2006 & 223,000 & 51,290 & 8,363 \\
\hline 2007 & 173,000 & 39,790 & 6,488 \\
\hline 2008 & 202,000 & 46,460 & 7,575 \\
\hline 2009 & 236,000 & 54,280 & 8,850 \\
\hline Jumlah & $1,069,000$ & 245,870 & 40,089 \\
\hline $\begin{array}{c}\text { Rerata/ } \\
\text { tahun }\end{array}$ & $\mathbf{2 1 3 , 8 0 0}$ & $\mathbf{4 9 , 1 7 4}$ & $\mathbf{8 , 0 1 8}$ \\
\hline
\end{tabular}

Melalui proses pre-treatment, kadar air diturunkan sebesar 66,7\% (menjadi kadar air 40\%). Maka potensi massa TKS mengalami penurunan dari 49.174 ton/tahun menjadi 32.782,7 ton/tahun (= 66,7\% x 49.174 ton/tahun).

\section{Nilai Kalor Bahan Bakar}

Nilai kalor dari TKS ditunjukkan pada Gambar 5, dimana TKS dapat dibagi menjadi dua jenis, yaitu yang mengandung minyak (oily) dan yang sudah tidak mengandung minyak (pure).

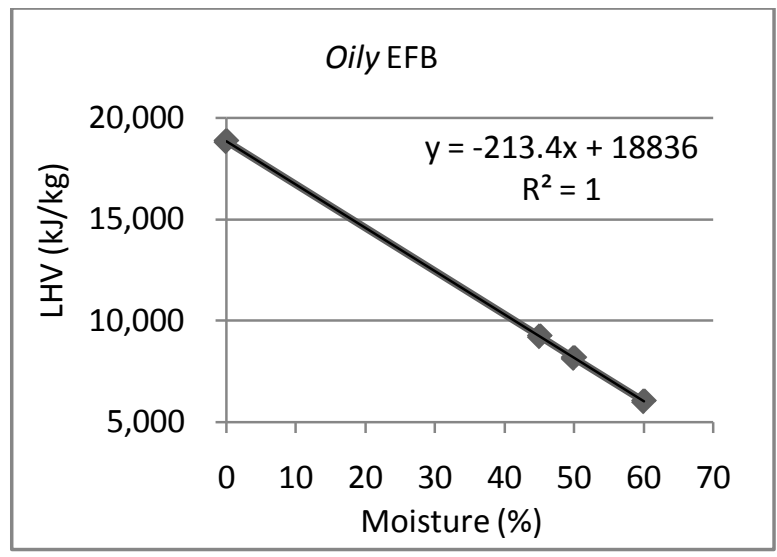

(a)

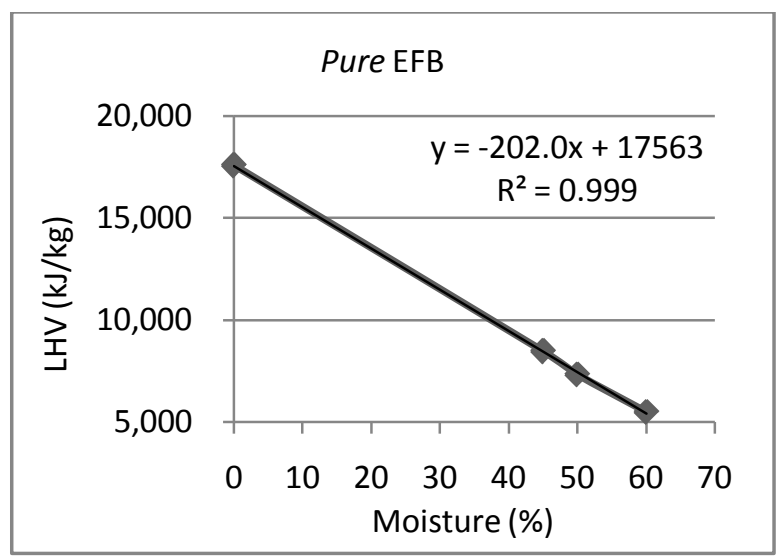

(b)

Gambar 5. Hubungan antara oily EFB dengan kadar air (a) dan pure EFB dengan kadar air (b)

Tabel 3.

Produksi cangkang di PKS Bunut dan Tanjung Lebar.

\begin{tabular}{ccccc}
\hline \multirow{2}{*}{ Tahun } & \multicolumn{2}{c}{ Bunut } & \multicolumn{2}{c}{ Tanjung Lebar } \\
\cline { 2 - 5 } & TBS & Cangkang(3,75 \%) & TBS & Cangkang(3,75 \%) \\
\hline 2005 & 197,000 & 7,388 & 165,000 & 6,188 \\
\hline 2006 & 216,000 & 8,100 & 172,000 & 6,450 \\
\hline 2007 & 206,000 & 7,725 & 146,000 & 5,475 \\
\hline 2008 & 201,000 & 7,538 & 144,000 & 5,400 \\
\hline 2009 & 230,000 & 8,625 & 152,000 & 5,700 \\
\hline Jumlah & $1,050,000$ & 39,376 & 779,000 & 29,213 \\
\hline Rerata/tahun & $\mathbf{2 1 0 , 0 0 0}$ & $\mathbf{7 , 8 7 5}$ & $\mathbf{1 5 5 , 8 0 0}$ & $\mathbf{5 , 8 4 3}$ \\
\hline
\end{tabular}


Kedua jenis TKS ini mempunyai nilai kalor yang berbanding terbalik dengan kandungan kadar air, dimana nilai kalor akan naik dengan berkurangnya kadar air dan pada saat bersamaan jumlah massa TKS pun berkurang akibat hilangnya jumlah kadar air yang dikandung TKS. Hubungan persamaan empiris antara nilai kalor dan kandungan air pada kedua jenis TKS ditunjukkan pada persamaan, $\mathrm{Y}=-213,47 \mathrm{X}+$ 18.836 untuk TKS yang mengandung minyak, dan $\mathrm{Y}=-202,07 \mathrm{X}+17.563$ untuk TKS kering [12]. Dalam persamaan ini, $X$ adalah kadar air dan Y adalah nilai kalor dalam kJ/kg.

Dari potensi jumlah bahan bakar (tandan kosong dan cangkang) dilakukan estimasi panas yang dihasilkan tiap jam dan estimasi daya listrik yang dibangkitkan dengan memperhitungkan daya listrik untuk konsumsi sendiri.

Dari nilai penjualan listrik dan pendapatan tambahan lainnya, dilakukan analisa keekonomian dengan faktor-faktor keekonomian yang ditetapkan.

\section{E. Harga Jual Listrik}

Harga pembelian tenaga listrik berdasarkan PERMEN ESDM No.30/2009[13], ditetapkan sebesar Rp 656/kWh x F, jika terinterkoneksi pada Tegangan Menengah, dimana untuk wilayah Sumatera, $F=1,2$. Dengan demikian, harga jual listrik menjadi sebesar Rp 787,2/kWh (= 1,2 x Rp 656/kWh).

\section{F. Pendapatan Lain}

Ada tiga jenis pendapatan lain selain penjualan listrik ke PT PLN (Persero). Gambar 6 menunjukkan proses pre-treatment TKS dan pemakaian TKS untuk memproduksi listrik. Dari proses tersebut didapat hasil sampingan yang dapat menambah pendapatan PLTBS, yaitu :

\section{1) Remnant Oil,}

Pada proses pre-treatment dihasilkan minyak pada saat pemerasan (remnant oil). Jumlah remnant oil yang didapat, diasumsikan sebesar 0,15\% dari jumlah TKS. Remnantoil yang didapat dari proses pemerasan TKS dikembalikan lagi ke dalam proses atau dijual ke pembeli yang menghendaki minyak kelapa sawit kualitas rendah. Harga jual remnant oil diasumsikan Rp $4.500 / \mathrm{kg}$, atau hampir sama dengan separuh harga Crude Palm Oil.

2) Abu hasil pembakaran,

Dari proses pembakaran TKS didapat abu sisa pembakaran. Abu ini digunakan untuk pupuk dan dijual ke petani di sekitar PKS. Jumlah pupuk yang didapat diasumsikan sebesar 2,7\% dari total TKS yang dibakar. Dari survei lapangan harga jual abu senilai Rp 800/kg.

\section{3) Penjualan Karbon,}

Dengan terkoneksinya listrik yang dibangkitkan dari bahan bakar carbon netural atau bahan bakar biomasa ke jaringan grid PT PLN (Persero)/jaringan interkoneksi Sumatera, maka listrik yang dihasilkan dapat mereduksi Gas Rumah Kaca (GRK) yang dihasilkan dari pembakaran bahan bakar berbasis karbon (fosil fuel) di pembangkit listrik yang telah terkoneksi dengan jaringan grid tersebut. Perhitungan emisi GRK yang dikurangi menggunakan emisi faktor jaringan interkoneksi Sumatera yaitu 0,743 tCO2/MWh [14]. Harga karbon sangat berfluktuasi bergantung kepada saat penjualan dan pembelinya, maka diasumsikan antara $15 € / \mathrm{t}-$ CO2 $-25 € / t-C O 2$.

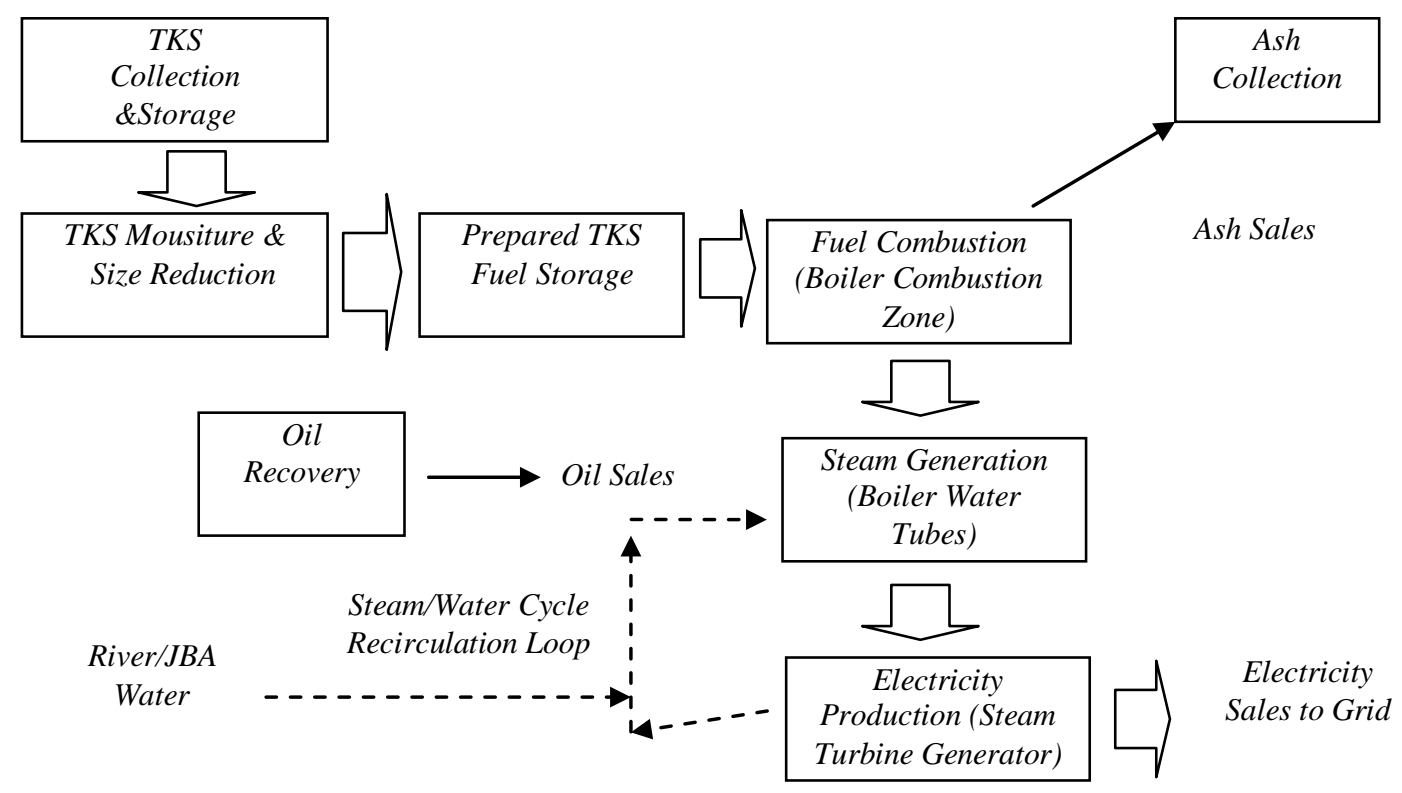

Gambar 6. Diagram proses Pembangkit Listrik Tenaga Biomasa Sawit. 


\section{G. Perhitungan Gas Rumah Kaca}

Perhitungan GRK menggunakan metodologi yang telah ditetapkan oleh UNFCCC (United Nation Framework Convention on Climate Chagge). Untuk jenis perhitungan GRK dalam studi ini, karena listrik yang dibangkitkan terkoneksi ke grid dengan bahan bakar biomasa dan berkapasitas di bawah 15 MW, maka dikategorikan ke Type I-D, yaitu Renewable energy projects, Category D-Grid connected renewable electricity generation [15].

Untuk menghitung jumlah pengurangan emisi GRK yang dapat dihasilkan dari PLTBS maka perlu ditetapkan emisi proyek (project emissions), emisi kondisi awal proyek (baseline emissions), dan kebocoran (leakage) berdasarkan persamaan yang ditentukan di metodologi AMS ID (Aprroved Methodology Small-scale I D) [15], sebagai berikut:

$$
E R_{G R I D, y}=B E_{G R I D, y}-\left(P E_{G R I D, y}+L E_{G R I D, y}\right)
$$

$$
\begin{aligned}
& \text { Dimana }
\end{aligned}
$$

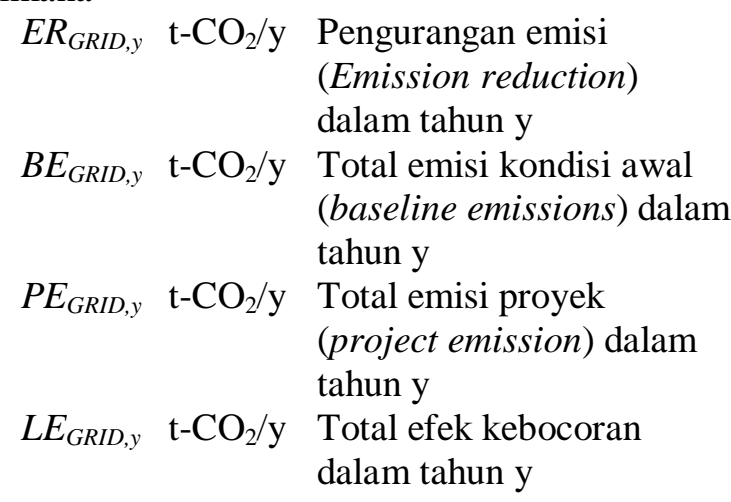

Emisi proyek, PEGRID, dianggap tidak ada (PEGRID=0), karena tidak menggunakan bahan bakar fosil. Emisi pembakaran hanya berasal dari limbah biomasa (tandan kosong, cangkang dan mungkin serat) yang dikatagorikan zero emission.

\section{Hasil dan Pembahasan}

Dari hasil pengumpulan data di lapangan didapat estimasi jumlah bahan bakar dan estimasi jumlah daya dalam MW yang dapat dihasilkan dari PLTBS Pinang Tinggi ini.

\section{A. Hasil Perhitungan Heat and Mass Balance}

Ketersedian bahan bakar biomasa (TKS dan cangkang) yang digunakan sebagai bahan bakar ditunjukkan di Tabel 2 dan 3. Dalam perhitungan, 90\% dari jumlah tersebut dianggap bahan bakar yang tersedia. Gambar 7 menunjukkan tekanan, $\mathrm{P}$ (bar), suhu, $\mathrm{T}\left({ }^{\circ} \mathrm{C}\right)$ dan entalpi, h $(\mathrm{kJ} / \mathrm{kg})$ di tiap fasilitas peralatan PLTBS yang digunakan untuk menghitung Heat and Mass Balance. Nilai P, T dan $\mathrm{h}$ di tiap fasilias peralatan ditunjukkan di Tabel 4.

Dari perhitungan heat dan mass balance, yang hasilnya ditunjukkan pada Tabel 4 , didapat beda entalpi dari inlet turbin dan outlet turbin. Nilai perbedaan enthalpi ini menentukan kapasitas PLTBS.

Jumlah konsumsi biomasa, masing-masing adalah TKS sejumlah 29.519,2 ton/thn (kadar air 40\%) dan cangkang sebanyak 21.735,6 ton/thn. Jumlah cangkang ini diasumsikan merupakan 90\% dari jumlah potensi cangkang pada Tabel 1 dan Tabel 2. Persentase suplai TKS dan cangkang adalah 60\%:40\%. Perbandingan ini ditentukan oleh jumlah cangkang yang maksimal hanya bisa mensuplai $40 \%$ dari total berat bahan bakar biomasa sawit (cangkang dan TKS).

Jika ketersediaan jumlah cangkang dapat ditingkatkan maka potensi kapasitas MW yang dihasilkan dapat lebih tinggi. Akan tetapi karena keterbatasan suplai cangkang maka suplai biomasa dari ketiga PKS, yaitu PKS Pinang Tinggi, PKS Bunut dan PKS Tanjung Lebar dengan jumlah tersebut di atas merupakan jumlah yang maksimal.

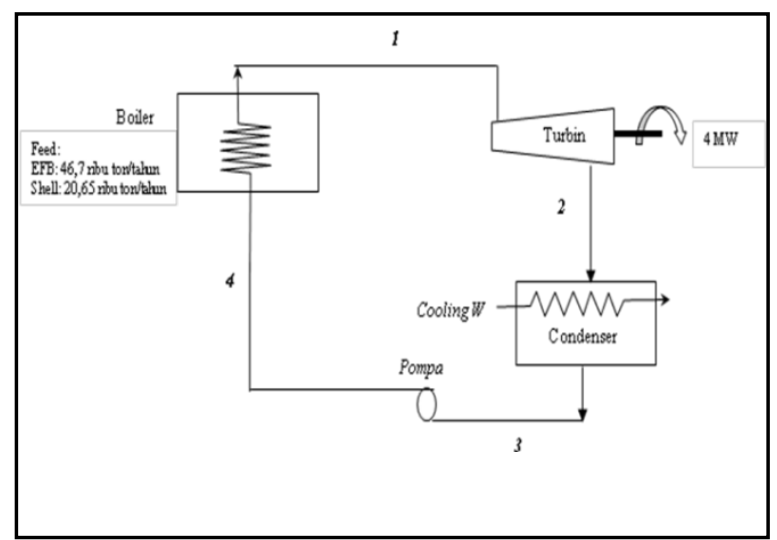

Gambar 7. Heat dan mass balance PLTBS.

Tabel 4.

Disain P, T dan h di PLTBS.

\begin{tabular}{cccrrc}
\hline Flow & m, ton/jam & $\mathbf{P , ~ b a r}$ & \multicolumn{1}{c}{ T, ${ }^{\circ} \mathbf{C}$} & $\mathbf{h}, \mathbf{k J} / \mathbf{k g}$ & Kondisi \\
\hline 2 & 25.2 & 0.11 & 47.80 & 2,442 & campuran \\
\hline 3 & 25.2 & 0.11 & 47.80 & 200 & saturated liquid \\
\hline 4 & 25.2 & 31.00 & 47.80 & 200 & subcooled liquid \\
\hline
\end{tabular}

Keterangan: $\mathrm{P}=$ tekanan, $\mathrm{T}=$ suhu, $\mathrm{h}=$ entalpi 
Dari ketersediaan biomasa tersebut maka kapasitas PLTBS maksimal yang didapat adalah 4 MW. Kapasitas lebih tinggi membutuhkan suplai bahan bakar terutama cangkang yang lebih banyak dari nilai rata-rata dalam 5 tahun (20052009).

Kebutuhan TKS dan cangkang rata-rata untuk PLTBS 4 MW ini adalah 4.100 ton/bulan dan 1.600 ton bulan. Dengan asumsi pengoperasian PLTBS adalah 7.446 jam (= 8.760jam x kapasitas faktor $85 \%$ ) dalam setahun, maka jumlah listrik yang dijual ke PT PLN (Persero) adalah sebesar 4 MW x 7.446 = 29.316 MWh

\section{B. Konfigurasi Fasilitas PLTBS}

Gambar 8 menunjukkan konfigurasi peralatan dari PLTBS pada studi ini. Pada dasarnya konfigurasi fasilitas peralatan PLTBS hampir sama dengan fasilitas peralatan di PLTU, yang berbeda pada fasilitas peralatan pre-treatment, dimana pada fasilitas ini kadar air TKS dikurangi dari 60\% sampai 40\%. Sedangkan cangkang langsung dimasukkan ke dalam tungku bakar, tanpa melalui proses pre-treatment

Tahapan proses pre-treatment TKS sebagai bahan bakar pada boiler PLTBS adalah sebagai berikut:
1. TKS disalurkan ke dalam sebuah drum pemisah dimana pasir, batu, dan bahan asing lainnya dipisahkan.

2. TKS kemudian dicacah dan di-press dalam Fibre Shredder dan Agitator Breaker/Press dimana kandungan moisture-nya akan berkurang hingga $40 \%$. TKS yang keluar dari alat akan berbentuk potongan dengan panjang berkisar antara 20-100 mm.

3. Selanjutnya TKS disimpan di dalam hopper, sebelum dibakar di unit boiler tunggal.

Jenis boiler yang digunakan adalah Grate Stoker Boiler dengan kapasitas 4 MW, dengan parameter kerja boiler 30 bar, $300^{\circ} \mathrm{C}$ dan 30 ton/jam.

Jenis steam turbine yang dipilih adalah jenis condensing steam turbine. Jenis ini dipilih karena mampu memberikan pembangkitan listrik yang maksimum dari steam yang disuplai. Exhaust dari steam turbine jenis ini harus dijaga memiliki kualitas di atas $90 \%$ karena dryness factor pada steam akan mempengaruhi efisiensi turbin, selain itu juga memacu terjadinya erosi fisik pada blade turbin. Untuk steam turbine kapasitas kecil, di bawah $3.000 \mathrm{~kW}$ dapat digunakan steam turbinestage tunggal, tanpa ekstraksi.

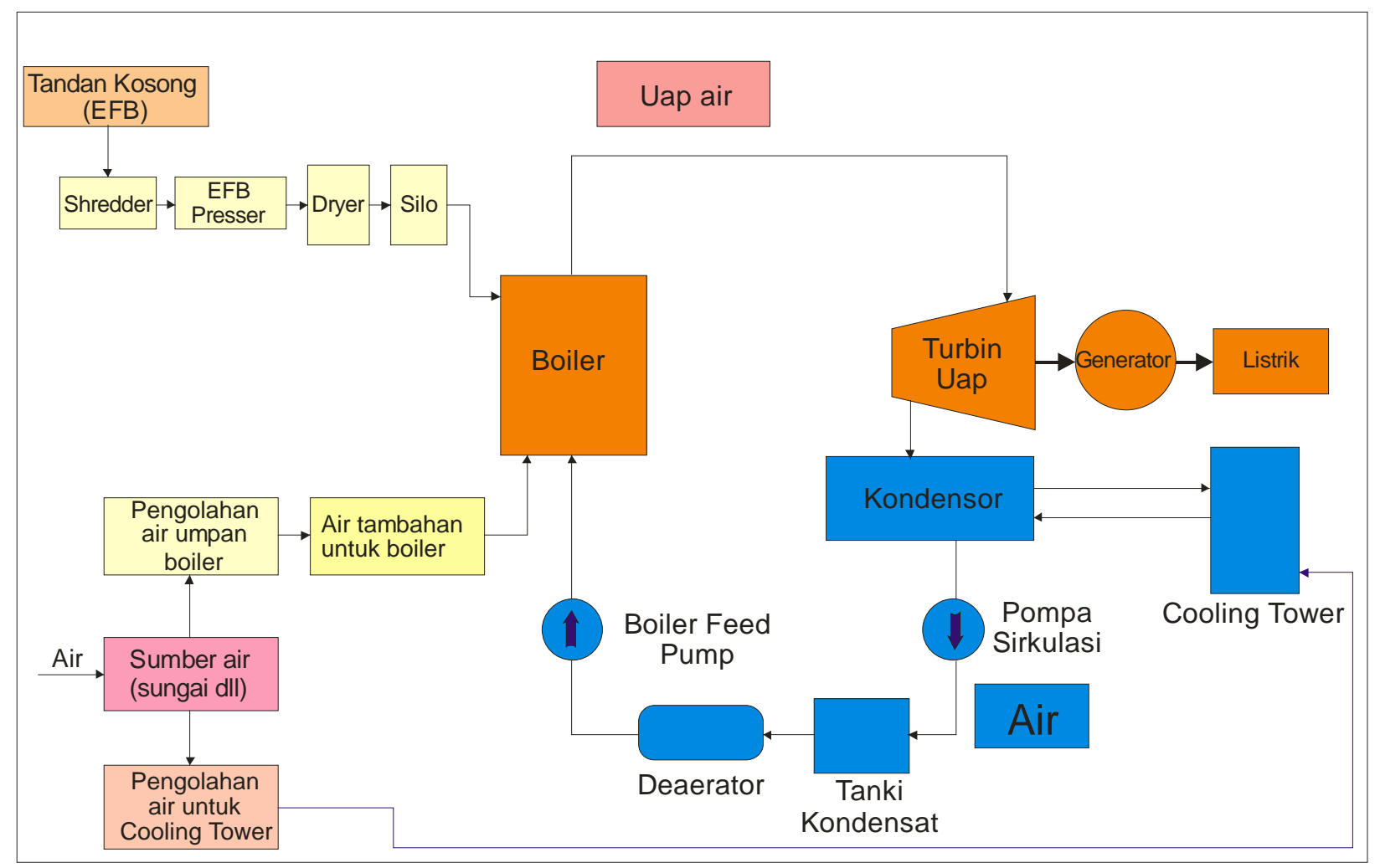

Gambar 8. Konfigurasi PLTBS. 
Spesifikasi turbin pada Gambar 7 adalah sebagai berikut:
a. Gross rating
: min. $4 \mathrm{MW}$
b. Tekanan exhaust : min. 0,135 bar perancangan
c. Kondisi steam
: min. 30 bar $/ 300^{\circ} \mathrm{C}$
d. Kapasitas steam
: min. 30 ton/jam inlet
e. Kondisi steam proses
: tidak ada
f. Estimasi auxiliary power
g. Estimasi net outputmaksimal
h. Jenis turbin
i. Speed
: min. 0,6 MW
j. Effisiensi
$: 3.000 \mathrm{rpm}$
: $70 \%$

Untuk sistem pendinginan kondensat digunakan sistem Closed Loop Cooling, dimana kebutuhan air pendingin untuk mendinginkan air kondensat disirkulasi dan didinginkan di cooling tower. Pada saat pendinginan di cooling tower ini terjadi penguapan yang membutuhkan make up water sekitar 5\% dari air yang disirkulasikan. Estimasi laju alir air pendingin min 1.000 ton/jam.

\section{Analisa Keekonomian}

Analisa keekonomian disusun berdasarkan asumsi yang ditunjukkan di Tabel 5. Sedangkan biaya pengoperasian PLTBS terdiri dari biayabiaya yang ditunjukkan pada table 6 .

Tabel 5

Asumsi Aspek Finansial.

\begin{tabular}{clrl}
\hline No & Parameter & Nilai & Satuan \\
\hline 1 & Faktor inflasi & 6 & $\%$ \\
\hline 2 & Hutang & 70 & $\%$ \\
\hline 3 & Equity & 30 & $\%$ \\
\hline 4 & Bunga & 11 & $\%$ \\
\hline 5 & Jumlah dipinjam & $40.726,8$ & Rp jt \\
\hline 6 & Equity & $17.454,3$ & Rp jt \\
\hline 7 & Total biaya proyek & $58.181,1$ & Rp jt \\
\hline 8 & Hari Produksiper tahun & 318 & Hari \\
\hline 9 & Produksi listrik & 25.316 & MWh \\
\hline 10 & Implementasi Proyek & 25 & Tahun \\
\hline & & &
\end{tabular}

Tabel 6

Biaya pengoperasian.

\begin{tabular}{clrc}
\hline No & Parameter & Nilai & Satuan \\
\hline 1 & Maintenance & 785,7 & Rp jt \\
\hline 2 & Asuransi & 261,9 & Rp jt \\
\hline 3 & Bahan bakar & 3658,1 & Rp jt \\
\hline 4 & Air dan zat kimia & 987,7 & Rp jt \\
\hline
\end{tabular}

Biaya pengoperasian didapat dari Bagian Teknis PKS Pinang Tinggi berdasarkan data pengoperasian boiler yang ada, yang digunakan untuk suplai listrik dan uap ke pabrik/PKS. Gaji pegawai tidak diperhitungkan, karena diasumsikan PLTBS ini dioperasikan oleh pegawai PKS Pinang Tinggi, yang dianggap telah mempunyai pengalaman dalam mengoperasikan boiler yang sudah ada. Pendapatan yang didapat dari hasil penjualan listrik dengan harga Rp 787/kWh, menghasilkan pendapatan sebesar Rp 19,9 milyar/tahun. Nilai IRR proyek adalah 2,03\%. Nilai investasi ini masih berada sangat jauh di bawah nilai IRR yang dapat diterima oleh PTPN VI, yaitu 15\%.

Pendapatan tambahan yang berasal dari ke tiga pendapatan tambahan diperhitungkan, sebagai berikut :

1. Minyak yang didapat dari pemerasan tandan kosong (remnant oil) sebesar sekitar 199,15 ton/tahun dengan harga diasumsikan Rp 4.500/kg. Potensi pendapatan remnant oil adalah Rp 896,2 juta/tahun. Harga minyak yang diperoleh dari tandan kosong diasumsikan naik $6 \%$ setiap tahun, sesuai dengan asumsi nilai inflasi.

2. Abu sisa pembakaran 5.184 ton/tahun, dengan asumsi harga abu yang diambil di tempat (di PKS) dengan harga Rp 800/kg, maka didapatkan penjualan abu sebesar Rp 4,14 Milyar/tahun, dengan asumsi jumlah abu adalah 2,7\% dari tandan kosong. Harga abu diasumsikan naik 6\% setiap tahun, sesuai dengan asumsi nilai inflasi.

3. Jumlah pengurangan emisi karbon/GRK adalah 19.063 ton $\mathrm{CO}_{2}$ per tahun. Harga karbon sangat fluktuatif, bergantung kepada saat penjualan dan kondisi pasar karbon, biasanya yang menjadi acuan adalah pasar karbon Eropa, dengan acuan harga EUA (European Union Allowance), dimana pada tanggal 21 Maret 2011, tercatat harga karbon adalah 16,89 €/t- $\mathrm{CO}_{2}[16]$. Pada studi ini harga karbon diasumsikan 15 (€/t$\mathrm{CO}_{2}$ ), maka didapat pendapatan sebesar Rp 19,92 milyar/tahun. Jangka waktu pendapatan dari penjualan karbon adalah 
sama dengan crediting period, yaitu 10 tahun.

Dari ketiga pendapatan tambahan ini, masingmasing dari penghematan minyak hasil perasan dapat menaikkan IRR sebesar 3,03\%, dari penjualan abu sisa pembakaran menaikkan IRR sebesar 9,03\% dan dari penjualan karbon menaikkan IRR sebesar 3,79\%. Total kenaikan IRR dari ketiga pendapatan tersebut sebesar 13,09\%. Sehingga nilai IRR dari 2,03\% meningkat menjadi $15,12 \%$. Batas persyarat keekonomian yang diajukan pihak manajemen PTPN VI adalah $15 \%$. Pay back period menjadi lebih cepat, yaitu menjadi 5 tahun.

Pendapatan tambahan merupakan faktor yang penting untuk kelayakan keekonomian PLTBS, karena pendapatan dari penjualan listrik saja memberikan nilai IRR yang sangat rendah.

Tabel 7 menunjukkan hasil analisis sensitivitas dengan mengambil parameterparameter yang memberikan dampak terhadap IRR, yaitu nilai investasi, harga jual abu sisa pembakaran, biaya bahan bakar dan harga karbon. Penurunan nilai investasi dan harga jual listrik sebesar $\pm 10 \%$, memberikan dampak masingmasing sebesar $\pm 1,78 \%$ dan $\pm 1,72 \%$ dari nilai IRR. Perubahan biaya bahan bakar dan harga jual abu sisa pembakaran sebesar $\pm 10 \%$ memberikan dampak yang hampir sama terhadap perubahan nilai IRR yaitu $\pm 0,53 \%$. Sedangkan perubahan nilai jual karbon sebesar $\pm 10 \%$ memberikan perubahan nilai IRR yaitu $\pm 0,26 \%$. Sensitivitas proyek sangat dipengaruhi oleh nilai investasi proyek dan harga jual listrik.

Tabel 7

Asumsi aspek finansial.

\begin{tabular}{llcl}
\hline Parameter & $\mathbf{- 1 0 \%}$ & $\mathbf{0}$ & $\mathbf{1 0 \%}$ \\
\hline Investasi & $17,24 \%$ & $15,12 \%$ & $13,34 \%$ \\
\hline Abu & $14,56 \%$ & $15,12 \%$ & $15,65 \%$ \\
\hline Harga karbon & $14,86 \%$ & $15,12 \%$ & $15,38 \%$ \\
\hline Bahan bakar & $15,64 \%$ & $15,12 \%$ & $14,58 \%$ \\
\hline Bahan bakar & $13.33 \%$ & $15,12 \%$ & $16,84 \%$ \\
\hline
\end{tabular}

Tabel 8

Daftar proyek CDM untuk PLTBS kelapa sawit di Indonesia.

\begin{tabular}{lc}
\hline Nama Proyek & Kapasitas (MW) \\
\hline MSS Biomass & 9,7 \\
\hline MNA Biomass & 9,7 \\
\hline Listrindo Biomass & 12,0 \\
\hline Belitung Biomass & 8,0 \\
\hline Nagamas Biomass & 3 \\
\hline
\end{tabular}

\section{Perbandingan dengan Proyek Lain}

Dari proyek pembangunan PLTBS yang telah menjadi proyek CDM diketahui bahwa di Indonesia ada 7 proyek, dimana 5 proyek yang memanfaatkan limbah kelapa sawit, yang lainnya memanfaatkan limbah kayu dan limbah kelapa [15].

Ke-lima proyek tersebut ditunjukkan pada Tabel 8. Dari keenam proyek, empat proyek pertama menjual produksi listriknya ke PT PLN (Persero) sedangkan sisanya memproduksi listrik untuk kebutuhan pabrik dan steam untuk proses pabrik PKS. Skema keekonomian pada Nagamas Biomass Project adalah untuk menggantikan bahan bakar diesel dari pembangkit listrik tenaga diesel yang memakai bahan bakar minyak, sehingga tidak dapat dipakai sebagai perbandingan terhadap PLTBS Pinang Tinggi.

Dari kapasitas listrik, PLTBS Pinang Tinggi relatif lebih kecil dibandingkan dengan PLTBS yang telah beroperasi di Indonesia. Hal ini berdampak terhadap pendapatan dari produksi listrik maupun penjualan kredit karbon dari produksi listrik yang dihasilkan. Walaupun perbandingan harga listrik ke empat PLTBS tersebut lebih rendah tetapi perbedaan tersebut tidak sampai kurang dari 70\% dari harga jualPLTBS Pinang Tinggi (tidak kurang dari Rp 550/kWh). Dengan semakin besarnya produksi listrik maka pendapatan dari penjualan kredit karbon semakin besar, sehingga dari ke empat proyek tersebut tidak dibutuhkan pendapatan tambahan selain penjualan kredit karbon untuk menaikkan IRR,

Dari segi investasi, PLTBS Pinang Tinggi relatif lebih mahal dibandingkan dengan PLTBS lainnya yaitu USD 1,6 juta/MW karena kapasitas pembangkit yang rendah. Sebagai perbandingan adalah nilai investasi PLTBS MSS senilai USD 1,2juta/MW untuk kapasitas 9,7MW[15] dan USD 1,6 juta/MW untuk 5,92 MW[17]. Dengan melihat perbandingan nilai investasi tersebut, dapat disimpulkan nilaiinvestasi PLTBS Pinang Tinggi dapat dinilai cukup layak untuk kapasitasnya.

Harga jual listrik Rp 787/kWh masih terlalu rendah untuk investasi di bidang PLTBS. Pendapat ini didukung hasil studi yang dilakukan oleh Asian Development Bank pada tahun 2006, terhadap potensi di PKS Gunung Meliau milik PTPN XIII. Dengan investasi sebesar USD 9,85 juta untuk membangun PLTBS berkapasitas 5,92 MW maka tidak layak secara keekonomian jika harga jual listrik masih berada di bawah 0,08 USD/kWh atau Rp 670/kWh[17]. 
Nilai investasi dari PLTBS yang tercantum di Tabel 8 tidak bisa didapatkan, akan tetapi dari hasil analisis sensitivitas dapat diduga bahwa investasi tidak semahal PLTBS Pinang Tinggi. Oleh sebab itu kelayakan keekonomian dapat dicapai relatif tinggi dan hanya dengan mengandalkan pendapatan tambahan dari penjualan kredit karbon didapat kelayakan keekonomian.

Pengurangan nilai investasi dapat dilaksanakan dengan mengurangi porsi investasi dari investor dengan menggunakan fasilitas yang telah ada, seperti pemanfaatan pembangkit diesel yang ada untuk kondisi darurat PLTBS, pemanfaatan ruang/bangunan untuk menghemat investasi bangunan, sehingga dapat mengurangi porsi investasi dari investor dengan mengalihkan sebagian porsi kecil investasi ke PTPN.

Investasi PLTBS dalam pemanfaatan TKS dan cangkang sebagai campurannya tidak dapat sepenuhnya memanfaatkan pendapatan dari penjualan listrik saja tanpa adanya tambahan pendapatan. Hal ini berarti investasi PLTBS adalah investasi dengan keuntungan yang minim dan resiko karakteristik TKS yang mengandung kadar air tinggi dan unsur alkali yang tinggi serta keberlanjutan suplai yang perlu diperhatikan dalam kurun waktu 5-10 tahun ke depan.

\section{KESIMPULAN}

Dari hasil studi kasus pada kelayakan teknologi dan ekonomi pembangunan Pembangkit Listrik Tenaga Biomasa Sawit (PLTBS) di PKS Pinang Tinggi didapat beberapa kesimpulan sebagai berikut:

1. Nilai investasi PLTBS di PKS Pinang Tinggi dan harga jual listrik sangat menentukan keekonomian proyek. Harga jual listrik yang ditetapkan oleh Permen 30/2009 masih belum mencukupi untuk mencapai kelayakan proyek PLTBS Pinang Tinggi.

2. Kelayakan keekonomian PLTBS Pinang Tinggi menjadi meningkat dengan adanya pendapatan tambahan yang berasal penjualan abu sisa pembakaran, pemanfaatan remnant oil dan penjualan kredit karbon. Kontribusi dari pendapatan tambahan tersebut terhadap kelayakan keekonomian akan semakin besar dengan meningkatnya kapasitas PLTBS.

3. Secara teknis dengan adanya PLTBS yang sudah beroperasi, kendala unsur alkali dan kadar air di TKS sudah bukan merupakan kendala yang berarti bagi pengoperasian PLTBS.

\section{UCAPAN TERIMA KASIH}

Ucapan terima kasih ditujukan PKS Pinang Tinggi, PT. Perkebunan Nusantara (PTPN) 6, yang telah memberikan data-data, informasi serta fasilitas kunjungan lapangan yang terkait dalam pembuatan makalah ini.

\section{DAfTAR Pustaka}

[1] Kantor Menko Perekonomian, 2004, "Kajian Pembiayaan Investasi Transportasi Perkotaan dengan Skema Debt-For-Nature Swap,".

[2] Jan Sandberg, Christer Karlsson, and Rebei Bel Fadhila, 2010, A 7 year long measurement period investigating the correlation of corrosion, deposit and fuel in a biomass fired circulated fluidized bed boiler, Applied Energy 88 (2011) 99-110, Elsevier.

[3] Michaël Becidan, Lars Sørum, Flemming Frandsen, and Anne Juul Pedersen, 2009, Corrosion in waste-fired boilers: A thermodynamic study, Fuel 88 (2009) 595604, Elsevier.

[4] Kementrian Lingkungan Hidup, Keputusan Menteri Kementerian Lingkungan Hidup No. 15/1996. Tentang : Program Langit Biru.

[5] Study on Power Project Using Biomass from Palm Oil Plantation in Indonesia, Tokyo Electric Power, Institute Economic and Energy Japan \& PTPSE-BPP Teknologi, March 2005.

[6] Materi Presentasi BPP Teknologi pada Forum Diskusi, PTPN 2 Biomass Feasibility Study, Hotel Sahid Jaya, Jakarta, 28 February 2011.

[7] MOU No:06.07/MoU/01/2010, PTPN dan PT PLN (Persero) tentang Kerjasama Pembelian Tenaga Listrik oleh PT PLN Persero dari Pembangkit Tenaga Listrik Berbasis Biomasa dan/atau Energi Terbarukan Lainnya.

[8] Kementrian Energi dan Sumber Daya Mineral, Rencana Usaha Ketenagalistrikan Nasional (RUKN) 20082027, Jakarta, 2008.

[9] PT. Perkebunan Nusantara (PTPN) VI Sumatera Barat dan Jambi, Informasi tertulis dari Bagian Teknis PKS Pinang Tinggi, Jambi, 2010.

[10] J.C. Igwe and C.C., Onyegbado, A Review of Palm Oil Effluent (Pome) Water Treatment, Global Journal of Environmental Research, 1(2):54-62, 2007 
[11] A.B. Nasrin and et.al, Oil Palm Biomass As Potentia Substitution Raw Materials For Commercial Biomass Briquettes Production, American Journal of Applied Science 583):179-183, 2008,

[12] General Guide to Consultants, Biomassbased grid connected Power generation, 2010

[13] Kementrian ESDM, Peraturan Menteri ESDM No. 30/2009 Tentang Penetapan dan Pemberlakuan Standar Kompetensi Tenaga Teknik Kelistrikan Bidang Pembangkitan Tenaga Listrik Sub Bagian Perancangan, Sub Bagian Perencanaan, Sub Bagian Konstruksi dan Sub Bagian Inspeksi.

[14] National Commision for Clean Development Mechanism. (2008). PDD and approval letter of CDM projects that have been approved by Indonesian DNA.

[Online]. Available: http://dnacdm.menlh.go.id/en/database/, diakses tanggal 17 Maret 2011.

[15] United Nations Framework Convention on Climate Change. (2011). Clean Development Mechanism [Online]. Available: http://cdm.unfccc.int/index.html, diakses tanggal 21 Maret 2011.

[16] Point Carbon [Online]. Available: http://www.pointcarbon.com/productsands ervices/carbon/, diakses tanggal 21 Maret 2011.

[17] Project Definitian report for waste to Energy in POMs, Gunung Meliau Cluster, Sanggau, West Kalaimantan, Indonesia, Asian Development Bank, 6 ADB Avenue, Mandaluyong City, Metro Manila Philippines., 2006 